\title{
Concepts of space and power in theory and in political practice
}

\section{Doreen Massey}

The Open University. Faculty of Social Sciences

Walton Hall, Milton Keynes. MK7 6AA United Kingdom

d.b.massey@open.ac.uk

Data de recepció: abril de 2009

Data d'acceptació definitiva: juliol de 2009

\section{Abstract}

This paper introduces particular conceptualisations of space and of power and brings them together in the idea of "power-geometries». It then explores the deployment of this concept in the context of the Bolivarian revolution in Venezuela, reflecting back on the nature of this engagement in political practice. Finally, it reflects briefly on how the concept itself has been enriched by this active political usage.

Key words: power-geometries, space, power place, Venezuela, Bolivarian Revolution.

\section{Resum. Els conceptes d'espai i poder en la teoria i en la pràctica politiques}

Aquest article introdueix unes conceptualitzacions específiques de l'espai i el poder i els relliga sota la idea de «geometries de poder». A continuació, el text explora el desenvolupament d'aquesta idea en el context de la revolució bolivariana a Veneçuela i reprèn el significat d'aquest compromís per a la pràctica política. Finalment, també es comenta breument com el mateix concepte ha estat enriquit per aquest ús polític actiu que se’n fa.

Paraules clau: geometries del poder, espai, poder, lloc, Veneçuela, revolució bolivariana.

\section{Resumen. Los conceptos de espacio y poder en la teoría y en la práctica politica}

Este artículo introduce unas conceptualizaciones específicas de espacio y poder y las relaciona mediante la idea de "geometrías de poder». A continuación, el texto explora el desarrollo de esta idea en el contexto de la revolución bolivariana en Venezuela y retoma el significado de este compromiso para la práctica política. Finalmente, también se comenta con brevedad como el mismo concepto se ha visto enriquecido por el uso político activo que se hace del mismo

Palabras clave: geometrías del poder, espacio, poder, lugar, Venezuela, revolución bolivariana.

Résumé. Les concepts d'espace et pouvoir dans la théorie et dans la pratique politique

Cet article introduit quelques conceptualisations spécifiques sur l'espace et le pouvoir et leurs liaisons autour de l'idée de "géométries de pouvoir». Ensuite, l'article explore le développement de cette idée dans le contexte de la révolution bolivarienne à Venezuela, et 
reprén le sens de cet engagement pour la pratique politique. Finalement, analyse comment le même concept a été enrichi par le usage politique actif qu'on en fait.

Mots clé: géométries du pouvoir, espace, pouvoir, place, Venezuela, révolution bolivarienne.

\section{Summary}

Space and power Conceptual lessons from political practice Power-geometries in action References

It is, perhaps, no longer innovatory to state that space and power are intimately intertwined. Intuitively, for instance, there appear to be places where power is concentrated (in global cities, perhaps, or in Washington DC, USA). There are those relations of power which are intrinsic to neoliberal globalisation and which tie different places together, subordinating some to the dictates of others. There are places within our own local areas which we might find it difficult to enter because they are alienating (we do not conform to the characteristics required of those who normally gain admission). And so on. Space and power imbue each other in a myriad of ways.

The purpose of this paper is first of all to reflect on this, and in particular to explore the resonances of this relationship at the conceptual level. That is to say, to explore the way in which the nature of the conceptualisation of space might be related to the nature of the conceptualisation of power. This, immediately, has political implications. However, in order to take this further, the paper then moves on to explore just one example of where this mutual imbrication of space and power has been recognised and has become a key element in proposals for political change. One reason for doing this is straightforward exemplification. It is also, however, to explore how the conceptual is itself developed in the context of political practice.

\section{Space and power}

The way in which space is conceptualised, in intellectual work, in social life, and in political practice, matters $^{1}$. It has effects, intellectual, social and political. In my own work, I have proposed three characteristics for an adequate conceptualisation of space. These are the following:

- First: that space is the product of relations (including the absence of relations). Space is a complexity of networks, links, exchanges, connections,

1. The argument of this section on space is spelled out in detail in the book For space (Massey, 2005). 
from the intimate level of our daily lives (think of spatial relations within the home for example) to the global level of financial corporations, for instance, or of counter-hegemonic political activists. Taking this opening proposition seriously immediately implies that space is a "product»: it is produced through the establishment or refusal of relations. It also implies, as a logical consequence, that space is in its very nature "social» (where social is taken to mean "more than individual», rather than simply «human») ${ }^{2}$. If there is to be a relation (or, indeed, a non-relation) there needs to be at least more than one thing to do the relating, or not.

- This leads to the second proposition about the characteristics of space. This is indeed that space is the dimension of multiplicity. Without space as a dimension it would not be possible for there to be multiplicity (in the sense of the simultaneous coexistence of more than one thing). Equally, and as the mirror image of this, without multiplicity space itself could not exist (space is the product of relations within multiplicity). Space and multiplicity are mutually constitutive.

- Third, and following directly on from these first two characteristics, space is always in a process of being made. It is always «under construction». It is never a fully connected and finalised thing like the «synchronies» proposed by structuralism for instance ${ }^{3}$. There are always relations which are still to be made, or unmade, or re-made. In this sense, space is a product of our on-going world. And in this sense it is also always open to the future. And, in consequence, it is always open also to the political. The production of space is a social and political task. If it is conceptualised in this manner, the dimension of space enters, necessarily, into the political (for if the future were not open there would be no possibility of changing it and thus no possibility of politics).

This bringing of the making of space into politics has been the motivation behind insisting on the importance of engaging with its conceptualisation. Space has so often (usually implicitly and without much thought) been consigned to the fixed and the dead (as Foucault had it), to the realm of the alreadygiven. One aim of this reconceptualisation is to bring it alive. Another aim is to rescue it from its negative counterposition with time. All too often space is thought of as the dimension that is the opposite of time It is the dimension without temporality (hence, «the fixed and the dead»). But if space is con-

2. This meaning of the term «social», implying multiplicity, also enables the inclusion of the world beyond the human, from «natural» phenomena to artefacts. This is an important extension and one increasingly addressed within Anglophone geography (see, for instance, Hinchliffe, 2007). The present paper, however, does not extend into this line of argument.

3. It is important to note this, because structuralism is often characterised as being «spatial», because instead of narratives it focused on structures. This is a grave misreading, that seriously misconstrues the spatial (as fixed, as something already achieved) and counterposes space and time (narrative or static structure; space as the absence of time). 
stantly being made, if it is the ongoing product of relationships and exchanges, then while it is most certainly a dimension that is different from time (see below) it is certainly not a dimension with no temporality within it ${ }^{4}$.

Nonetheless, even if bringing space alive in this way enables its more productive insertion into the political, it must be emphasised (as will be explored further below) that this is in no way to suggest that any particular conceptualisation (including this one) will lead in deterministic fashion to any particular political position. This particular conceptualisation does, however, force on to the agenda certain political questions. If time is the dimension of succession and of change, space is the dimension of contemporaneous multiplicity. For that reason, as has been argued, it is the dimension of the social.

It is space as a dimension that poses to us that most fundamental of sociopolitical questions: how are we going to live together? It is space as a dimension that offers up the challenge, the pleasure and the responsibility of the existence of "others", and of our relationship to them.

This, then, is one side of things - the side of space. There is, however, another side to the argument of this paper, which is that, not only is space utterly imbued with and a product of relations of power, but power itself has a geography. There are cartographies of power. The concept that I have proposed, and that I continue to find most useful, in exploring this two-sided definition is "power-geometry" (Massey, 2005, 2007).

That power has a geography is something that is known implicitly - the opening brief examples implied as much. Moreover it is also the case that this proposition applies to all forms of social interaction that are brought together under this umbrella term — whether it be the power of violence, or of authority, or of seduction (the various forms of «soft power» so commonly now recognised as being deployed, even alongside physical violence), of domination, of creativity... (indeed, it may be that these different modalities of power have inscribed within them, as a function of their different natures, propensities towards distinct geographies — see Allen, 2003). Or again, the different instances of a social formation (the economic, the political, the cultural, for example) may each be analysed as having their own power-geometries, even though undoubtedly they will be related to each other, inflect each other, and quite probably reinforce each other. (In the United Kingdom, for example, it is quite possible to discern power-geometries in politics, in the economic sphere through the geography of the relations of production and distribution, and in the cultural formation. It is also undeniable that the three - each of them strongly peaking in the south east corner of the country - feed off each other and reinforce each other. The spatial centralisation of all of these power-relations in London is one of the cardinal facts of British society. It is a crucial aspect of the national democratic deficit. Most parts of the country barely have a voice.)

4. Again, this argument is fully spelled out in For space. Moreover, and importantly, the corollary is also true: that time, itself produced also out of interaction, requires the existence of space (see, for instance, Adam, 1990). 
Equally, these power-geometries exist at all spatial levels. The unequal geographies of power that underpin the chasms of economic inequality that are a product of neoliberal globalisation are only the most obvious example at the level of the international. The idea of "power-geometries», then, is simply an attempt to capture both the fact that space is imbued with power and the fact that power in its turn always has a spatiality.

The concept has, however, a number of other significant implications. First, the very notion of power-geometry brings with it the implication that power itself is relational. This is not a question, in fact, of a geography of power, but of a geography of power-relations. We should, therefore, immediately enter some modifications to the intuitive descriptions of space/power at the very beginning of this paper. It is not that all "power" is concentrated in global cities, or in Washington DC, but rather that the power-relations are focused there. What global cities have are the resources, the economic weight, often backed up by political and cultural influence. Their power is exercised relationally, in interaction with other places (one might think of the relation between the financial City of London and a country in the global South, for instance). This in turn opens up particular possibilities for politics. In particular, it implies that a significant political task is building a politics of relations. This may be between social groups, between local places, between countries, or whatever. It also implies a politics of building alliances, maybe between political groupings or struggles in different parts of the world. It is important to note, however, that in building such alliances, or chains of equivalence (Laclau and Mouffe, 1985), each component political grouping will itself be modified. A relational view of the world entails that power is not an external relation between already finally pre-constituted entities. On the contrary, the very fact of relationality is part of what constitutes those entities themselves. Further, it is important to note what a relational understanding of power (and space) does not imply. For instance, it stands against those notions of energy or force that see them as internally derived; as the internally generated motiveforce of being, or autarchic self-creation. Even creativity does not occur in a vacuum; rather it is necessarily social; that is to say, relational (Hallward, 2007; Gilbert, 2008). Finally, on this understanding, power will never be abolished. The aim of a progressive politics is thus not to do away with power. As Devine writes, "Twenty-first century socialism, like any form of socialism, is ultimately about power and power relations» (2007, p. 115).

\section{Power-geometries in action}

In itself, the term power-geometry does not imply any specific form (any specific geometry). It is a concept through which to analyse the world, in order perhaps to highlight inequalities, or deficiencies in democracy. It is in this mode an instrument of potential critique. It may also, however, be an instrument through which to imagine, and maybe to begin to build, more equal and democratic societies. This point was brought strongly home to me in the spring and 
summer of 2007 when I received an invitation to visit Venezuela to participate in the processes of change underway as part of the Bolivarian project of building a socialism of the twenty-first century. After a resounding election victory in December 2006 this project, led by Hugo Chávez, had moved in a more explicitly socialist direction (its own characterisation) and in this context five "motors" had been set out to carry the revolution forward. The fourth of these motors is to build "a new power-geometry» (la nueva geometria del poder $)^{5}$. Here, then, a geographical concept is being put to positive political use. Indeed, as will be seen, part of what lay behind the proposal was an impressive recognition of the existence and significance, within Venezuela, of highly unequal, and thus undemocratic, power-geometries.

In its particular form of the fourth motor, the "new power-geometry" referred to the need to reorganise the geopolitics of Venezuela, the geopolitical organisation of its territory. Importantly, however, this was recognised to refer both to the formal geography of its democracy and to the form of the power-relations that it entailed. Schematically, it is possible to spell out these aspects separately. Thus, on the more purely geographical side, the intent is to distribute "power" and participation more evenly - to give more voice to the vast regions of the south of the country, that stretch away from the towns and populated areas of the coast towards the headwaters of the Amazon; to give more voice to smaller communities; and to give more voice to indigenous communities ${ }^{6}$. On the other side, there was recognition of the need also to address the nature of the power within these power-geometries. By the time of Chávez's election in 1998, the formal state apparatus in Venezuela, including its mechanisms of representative democracy, were completely delegitimised. The long period of puntofijismo, the subsequent chaos and farce, the extremely high levels of corruption..., all of these things meant that it was not feasible simply to continue with the forms of state and democracy that had been inherited ${ }^{7}$. The most important structural innovation here has been the introduction of participatory democracy «from below».

The mechanisms for the implementation of these changes are more complex than can be elaborated here, but a few points can be made ${ }^{8}$. One small and symbolic one is the proposal to call all basic-level settlements within the democratic structure "cities». The politics of this change revolved around the

5. The five motors are: «1. Ley habilitante: via directa al socialismo, 2. Reforma constitucional: estado de derecho socialista, 3. Moral y luces: educación con valores socialistas, 4. La nueva geometría del poder: el reordenamiento socialista de la geopolítica de la nación, 5. Explosión del poder communal: democracia protagónica, revolucionaria y socialista».

6. The recognition of the multi-ethnicity of the country has been an important thread in the Bolivarian project. This has included both indigenous people and those of African descent.

7. This was one reason for the delivery of social programmes through parallel structures, such as Bolivarian circles, and missions.

8. One source is the Proyecto de Reforma Constitucional, voted on, and lost, on $2^{\text {nd }}$ December 2007. There is also much legislation, before and after that date, that moves in the same direction. 
linguistic connection between city and citizenship (ciudad y ciudadania) and the equality of rights and responsibilities, that inhere in citizenship, that had previously been lacking. In symbolic terms it proclaims that every geographical collectivity, however small and wherever it is in the country, has the same political status. As such, it is a small step in the building of a new power-geometry. It is also, as is much of the Bolivarian revolution, about the recognition and assertion of voice, and of a multiplicity of voices. It resonates in other words with the conceptualisation of space (as a multiplicity) that was laid out in the previous section.

Much bigger have been the changes wrought through the introduction of elements of participatory democracy. This has taken place through the initiation of a process of the formation of "communal councils» (consejos comunales). These are formed by people themselves (there are posters and leaflets and so forth detailing how to do it). Each communal council brings together about 400 households (this number can be adjusted in indigenous and rural areas to conform with local customs and conditions). There is then, in principle, a successive aggregation of these councils up to national level, forming a structure parallel to that of the elected state. Broadly speaking, the aims of these councils are on the one hand to take unto themselves the collective self-management of their neighbourhoods and on the other hand to maintain pressure on the elected state (the pressure of constituent power on constituted power). In terms of power-geometries some things are immediately evident. This is an attempt (again) to shift political voice towards those who previously did not have such a voice - the poor in the cities being the clearest example. Moreover this political voice exemplifies a different kind of power-relation. It is not about representative democracy and the individualism of voting; rather it is about collective organisation, decision-making, management and campaigning. Moreover, this very process of self-government, the very formation of communal councils, is one that, being new, has to be learned. It is thus in itself empowering. It is part of the process of formation of popular power (poder popular, or poder protagónico). It is possible to see here, in other words, how both the very nature of power-relations and the geography of those relations might be changed. Truly an attempt to shift the whole nature of the national, political, power-geometries.

Let us, then, reflect briefly on this mobilisation of the concept of powergeometry, primarily at this point from the point of view of political practice but bearing in mind also the conceptual arguments elaborated at the beginning of this paper.

First, if power is relational then it is necessary to consider not just entities (such as, for instance, smaller settlements in rural areas, or communal councils) and their establishment and recognition, but also the wider relations of power within which they are set. Thus, in the case of communal councils, in any political evaluation it is necessary to take into account a host of questions such as: where is control over their recognition located? (communal councils have to be officially recognised in order to participate in the new structures) and 
where is control over the distribution of resources to and between communal councils located? Such considerations will influence greatly the reality of the project to distribute democratic participation more evenly. So too will the issue of resources and capabilities. If the aim is greater equality, if power is relational, and if the starting-point is gross inequality (which it is in Venezuela), then the establishment of structures and rights has to be supplemented by an expansion of resources and capabilities, human and physical, in those areas currently underendowed.

Second, there is the question of time and temporality. The intuitive image of a power-geometry might be as a kind of diagram, or map. It is essentially a spatial concept, and this map-like image of it would fit with those understandings of space that see it as a flat, finished, surface or network. As something already completed ${ }^{9}$. As, indeed, dead. Yet as soon as that is said it is obviously incorrect. For a power-geometry is precisely a product of relations, and relations are social processes, and very much alive. In that sense power-geometries precisely exemplify the conceptualisation of space as always under construction. The spatial as imbued with temporality.

This is richly evident in the policy of power-geometries in Venezuela, and it raises reflections both political and conceptual. It is evident in a situation, as in Venezuela, where establishing a new power-geometry is part of politics, that power-geometries are processes. They are not diagrams on a page; they are the evolving outcome of processes of socio-political contestation. Thus, politically, what matters is not only the initiating policy statements and formal definitions, the declarations about communal councils and the delineation of territories, but the socio-political practices of their realisation. And these practices will reflect and depend on everything from the general political culture of the nation to the behaviour of individuals (the microphysics of power).

Furthermore, in building a new power-geometry it is necessary to take account of this essential dynamism and to make it part of the politics. In particular, it is necessary to grapple with the possibility that there may be more than one temporality within a power-geometry, and that there may be dislocations between them. There is a very clear case of this in Venezuela. Thus, one of the most frequent criticisms of the Bolivarian process is that it is producing a situation (a power-geometry) which is too focused on the centre, specifically in the figure of Chávez ${ }^{10}$. One response to this is that this (acknowledged but perhaps inevitable) centralisation will be balanced by the development of popular forces through, for instance, the communal councils. Whether or not one thinks this is an adequate response, the point to be made here is that it is to attempt to balance two very different temporalities. On the one hand, the power-resources of the president can be established almost imme-

9. For a discussion of the connection between maps and problematic concepts of space, see For space, chapter 11 .

10. There are undoubtedly real issues here, but some useful light is thrown on them by Ernesto Laclau's analysis of populism (Laclau, 2005). 
diately, through the passage of laws. On the other hand, the power-resources of small communities in the south of the country, for instance, or in the poor barrios of the coastal cities, will take years to develop. From economic weight, to cultural resources, to the forming of collectivities, to the very confidence that one can raise one's political voice at all, all these things have been seriously lacking in such places and among such groups. Here the passing of legislation is merely an enabling act. The bringing to fruition of the aim will take many years and much hard work. Meanwhile, the imbalances within the emerging power-geometry are likely to persist.

A further reflection arises from the fact that in Venezuela the concept of power-geometry is being mobilised specifically in the sphere of politics. However, as was argued in the previous section, there are geometries of power in all instances of society. Moreover they relate to each other and, if there is any general tendency, it is that they are likely to reinforce each other. For that reason the real functioning of a power-geometry within the political will depend also on that within the economic, that within the distribution of educational resources, that within the cultural sphere, and so on. In the Venezuelan context, one thing this means is that other motors of the revolution will be important contributors to the establishment of a new, more democratic and egalitarian, political power-geometry. One might, for instance, cite here the third motor (moral y luces) with its emphasis on popular education. Most particularly, this interdependence of power-geometries within different spheres highlights the importance of economic reform — the building of what is said to be a new productive economic model that is collective and cooperative. Such a process (also likely to be long and conflictual) would contribute greatly to the reality of a new geometry of power within the political sphere.

One final, brief, reflection - and one which relates closely to recent debates within geography - concerns the role of "place» in the building of this new power-geometry. The basic building-blocks of the new popular, participatory, forms of democracy are places. They are groups of households in which the grouping is through criteria of spatial contiguity (they form a neighbourhood, or settlement, etc.), and much of the task which they have been set concerns the forming of that place into a collective to address issues of local (withinplace) self-management. This is typical of all such initiatives, and indeed representative democracy also typically functions through a territorial base. It does, however, raise reflections, again both political and conceptual.

In the constitutional proposals in Venezuela "communes» were defined as the social cells of the territory, each of which is to constitute the basic and indivisible nucleus of the state («serán las células sociales del territorio [...] cada una de las cuales constituirá el nucleo territorial básico e indivisible del Estado»). From the point of view of the concept of space advocated here, and from that of power-geometries, space is not simply an aggregation of territories; it is also a space of flows and relations. In its turn this implies that "places» are never homogeneous or closed. Each place is a node of relations, an internal complexity. And this in turn implies that "places» are the products of negoti- 
ation, conflict, competition, agreement, and so forth between different interests and positions. This is in no way to throw doubt upon the proposals. But it is to argue that these «basic nuclei» will, as political entities, be an evolving result of the process of building participatory democracy rather than a presumed already-existing coherence that one can take as an input to the process. (Once again, the political and the conceptual engage with each other in productive conversation.)

The political implications are significant. One aspect is, as already mentioned, that the process of building these nuclei into political entities (the consejos comunales) is a long, difficult, and potentially conflictual one. The existence of collectivities cannot be taken as given. On the other hand this very process is itself a learning process, and an empowering one. (It might be noted that this form of territorial base is thus in fact very different from that of representative democracy. In representative democracy the territorial base is effective only as the unit of aggregation of individuals. In participatory democracy and local self-management, however, the territorial base is required also to be effective as the scaffolding for the constitution of a collective voice. It is also different, moreover, from those autonomous communities that establish themselves, also in places, as demonstrations of the possibility of political alternatives, for in their case some kind of agreement, or commitment to the project, is assumed from the start. This is important, for it means that there is no need to confront radical differences in interests or political position. In the places of the consejos comunales any such differences will have to be addressed, and this is important — and positive- politically.) Furthermore, there is some evidence, for instance in the detailed empirical investigations in Caracas by Miguel Lacabana and Cecilia Cariola, that this emerging place-based collectivity is beginning in itself to give people from the poorer barrios a confidence and, very interestingly, that this place-basis (anclaje territorial) has enabled people from these barrios to break out of their previous territorial enclosure (a romper el encierro territorial) and participate more widely in the public and institutional spaces of the city as a whole (Cariola and Lacabana, 2005).

Before turning to the final section, which will reflect some more on the engagement between the theoretical and the political, there is one further point to be made. This is that, although the only way that the concept power-geometry is mobilised consistently and explicitly in the Bolivarian project is in relation to the restructuring of politics and democracy in the internal political sphere, there are of course numerous other ways in which the project is having considerable effects on other geometries of power. This is especially the case at the global level where the insistence has been on the attempt to create a world that is more explicitly politically differentiated - multipolar as opposed to unipolar. This has taken many forms, including perhaps most importantly, the moves to create a more distinguishable voice within Latin America (from ALBA, to Telesur, to PetroCaribe, to the Banco del Sur, and so on). It also included until abolished by an incoming Conservative mayor of London, an equal exchange agreement between Caracas and London that clearly challenged 
the neoliberal mantras that all relations between places should be those of the market and that places must compete against each other. No, it said, they can cooperate. This was an explicit politics of relations (a politics of place beyond place, as I have called it) and quite clearly a very small, but symbolic, remodelling of the existing power-geometries of neoliberal globalisation. And, although indeed tiny, its potential symbolic significance was ironically confirmed when the incoming Conservative mayor cancelled the agreement almost immediately on taking office.

\section{Conceptual lessons from political practice}

The previous section, then, presented one small story of the mobilisation of a geographical concept in political practice. A concept being employed to do real work. This kind of deployment raises a host of questions. One of these is the issue of one's responsibility, as it were, for and towards a concept when it is deployed politically, and especially when as in this case the concept has travelled from its place of origin to be deployed elsewhere. (This latter aspect raises particular questions for postcolonial geographies.) There have been, for instance, detailed reports of how Deleuzian concepts — of smooth space and of deterritorialisation for instance- have been made use of by the Israeli Defence Forces in waging war in Palestinian settlements (Weizman, nd). It is clear that «concepts» in themselves do not guarantee particular political usages or outcomes.

The case described in the last section was rather different from the Deleuzian one in that the concept of power-geometry was being deployed in a political context sympathetic to the purposes for which it had originally been devised. Here what was fascinating was the way in which the concept was further moulded by the very fact of its engagement in political practice. There were a number of aspects to this. First, as already mentioned, the idea of powergeometries was first developed as a tool of critique for use within the United Kingdom under Margaret Thatcher and her forebears ${ }^{11}$. The very fact of its use in a quite different situation —one of trying positively to construct a more progressive power-geometry - had effects. One of these was the transformation of the concept into one in which temporality, and indeed the possibility of a multiplicity of temporalities, was explicit. As academics, we write often of things being processes; it has been a long commitment of the social sciences. Marx stressed that capital is a process. And most recently the emphasis on the continual becoming of things, on verbs rather than on nouns, and so forth, has brought that aspect of conceptualisation, along with its potential political implications, once again to the fore. But it is the reality of being in the midst of a thing-as-a-process that brings home the full meaning and import of words that can roll so easily off the tongue. 
Or again, witnessing the active use of the idea of power-geometries enriched the concept in a variety of ways. Thinking about how it could relate to a whole range of different kinds of power-relations - popular, participatory, collective- and appreciating even apparently small things such as the intended symbolic force of calling all settlements "cities», gave the concept a richer, more qualitative sense. It elaborated still further, for me, the range of possibilities of what might be a "power-geometry».

\section{References}

ADAM, B. (1990). Time and social theory. Cambridge: Polity.

ALLEN, J. (2003). Lost geographies of power. Oxford: Blackwell.

CARIOla, C.; LaCABANA, M. (2005). «Globalización y metropolización: tensiones, transiciones y cambios", in CENDES-UCV: Venezuela visión plural: Una mirada desde el Cendes. Caracas: Cendes.

DeVINE, P. (2007). «The political economy of twenty-first century socialism». Soundings: a journal of politics and culture, 37, p. 105-115.

GilberT, J. (2008). Anticipation and culture. Oxford: Berg.

HallWard, P. (2007). Out of this world: Deleuze and the philosophy of creation. London: Verso.

Hinchliffe, S. (2007). Geographies of nature. London: Sage.

LACLAU, E. (2005). On populist reason. London: Verso.

LAClAU, E.; MOUFFE, C. (1985). Hegemony and socialist strategy. London: Verso.

MASSEY, D. (2005). For space. London: Sage.

- (2007). World city. Cambridge: Polity. 